\title{
The Effectiveness of Outdoor Learning Model in Improving Science Learning Outcomes in Elementary Schools
}

\author{
Subarkah $^{1}$, Suyitno $^{2}$, Subuh Anggoro ${ }^{3}$

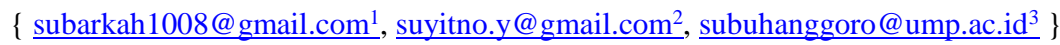 \\ ${ }^{1,2,3}$ Universitas Muhammadiyah Purwokerto
}

\begin{abstract}
This study aims to improve the cognitive learning outcomes of Grade VI students of SD Negeri 1 Kebarongan on Science Learning. This research is Classroom Action Research. The series of this research consisted of two cycles, in which each cycle contained four stages: (1) planning; (2) implementation of the action; (3) the observation and evaluation and; (4) reflection. The application of the outdoor learning model is carried out to help improve student learning outcomes. The results of the study were that the initial conditions, the percentage of completeness obtained in the science subject of vegetative propagation material for class VI State Elementary School 1 Kebarongan were $41 \%$ with average value of 63.33 .First cycle, the classical grade point average was 72.38 , and the completeness was $73 \%$. There was an increase in the mean score of 86.7, and the classical fullness was $95.23 \%$ in the second cycle. From the results obtained in this study, it can be concluded that the application of the Outdoor Learning Model can improve Science learning outcomes for Grade VI elementary School students.
\end{abstract}

Keywords: Effectiveness, Learning Outcomes; Science Learning; Outdoor Learning Model

\section{Introduction}

A country is said to be advanced if it can compete during the globalization era. There are various ways can be done to advance the country, one of which is through improving the quality of the country's education. One measure of whether the country is a developed or developing country can be seen from the progress of its education. In line with what was conveyed by Turkkahraman that in developed countries, the knowledge generated through research and education is not only used to realize social and economic, but is also used for the personal development of individuals in that country. In addition, education is a means to create the nation's next- generation who will compete in the world arena [1].

Education is a prerequisite for development and also an effective way of making informed decisions. This means that education is expected to create a world that is safer, healthier, and more prosperous so that it can improve living standards by changing individual visions and perspectives [2]. Agreeing with the above statement states that rapid progress in the field of science and technology requires competent, skilled and professional Human Resources. The possibility of advancing the country is challenging to grasp if a country produces output educational that is not competitive, unskilled, and unprofessional.

Therefore, if you look at the current situation and condition of education in Indonesia in particular, there are still many schools that need educational facilities, more and more children 
are dropping out of school at every level, for example, in primary schools from 34 regions in Indonesia, the number of children dropping out of school reaches 39,213 ones, changes in the education curriculum that are too fast, the minimum skills were shown by educators, and the absence of reinforcing character instruction, are some of the things that are the reasons in the field of education challenging to achieve.

Darmawan states that the increasingly advanced times and globalization as it is today are marked by the increasing product and use of information technology; this is the basis for shifting the conception of teaching and learning activities to modern learning [3]. It means that, in the current era of globalization, there are many possible ways to improve the quality of education, one of which is through the use of information technology in the learning process both as a tool, as multimedia, and so on. The use of information technology is a solution for teachers to innovate in their learning. Innovating in education is the obligation of a teacher, because it is hoped that it can improve student learning outcomes for the better, and the learning process will be more effective and efficient. This is in line with the opinion of Pandolfini which states that as much as possible, a teacher can create a more innovative environment for effective teaching and learning [4].

In addition, in order for the teaching and learning process to run effectively, a learning model is needed that is by the character of the students, the subjects delivered, the atmosphere, and the supporting infrastructure. Kazu states that in the learning system that is carried out, each individual in the group is very dependent on the program and the desired teaching method. This means that teachers are advised to recognize and know the learning characteristics of their students, with this it is likely that teachers can find and determine learning methods and models that are by the features of their students both in terms of learning styles, interests, and development of students' knowledge [5].

The teacher, as a facilitator in the world of education, especially in schools, is often unable to work correctly. This is indicated by the fact that learning activities in the classroom have not been managed properly. The teacher has a dominant role and is too active, and conventional style is usually dominated by direct and one-sided instruction [6].

Traditional learning approaches assume that there is definite knowledge that students must know. The same thing is expressed by Ahmed In North America, for many years, the traditional teaching style or teacher-centered teaching was more dominant in higher education. In conventional classrooms, students become passive, more precisely only receiving the knowledge and wisdom of the teacher [7]. They are not dominant in learning. It can be said that every teacher must be able to place himself in every lesson so that it is not always the center of student learning, one of which is by creating learning that activates and enhances student independence, for example through a model, approach, method, or learning media. Another problem that also tends to be seen is that the style of delivery of material by the teacher is too monotonous, meaning that the teacher only relies on his abilities without using learning tools or media, so this causes student motivation to learn may be reduced in the end, it will also have an impact on the decline in student learning outcomes.

Good learning can be shown from a conducive learning atmosphere [8]. Because in an era of rapid science and technology development, teacher professionalism is not sufficient only with the ability to teach students, but student learning activities [9]. One of the characteristics of a professional teacher is how he chooses the right strategy and learning media in each subject matter that he teaches. Accuracy in using the learning approach carried out can affect student activity and achievement in learning activities. The selection of learning methods should adjusted to the learning material, the level of student intelligence, and local environmental conditions. 
Learning Science in Elementary Schools is a means of introducing and imparting knowledge to children, including to think critically and behave scientifically. According to Mulyasa, Science learning in elementary school aims to enable students to[10]: (a) get confirmation of the majesty of God Almighty based on the manifestation, beauty, and orderly nature of His creation; (b) broaden knowledge and understanding of scientific concepts that are useful and applicable in everyday life; (c) broaden curiosity, good attitude and realize the interrelationships between science, environment, technology and society; (d) add process skills to identify the environment, solve problems, make decisions; (e) foster sensitivity to participate in caring for, protecting, and preserving the natural environment; (f) increase sensitivity to appreciate nature and all its regularities as one of God's creations; and (g) acquire knowledge, concepts, and basic science skills as a basis for continuing education to junior high school. The success of this learning will determine its behavior towards the natural environment.

Ironically, the student achievement at $6^{\text {th }}$ grade State Elementary School 1 Kebarongan in the Natural Science subject, the subject of vegetative propagation of plants, is still low. From 21 students, there only ten students who mastery or had scores above or the same as minimum completeness criteria in Natural Science learning on the subject of vegetative propagation of plants. So, while 11 students had not yet experienced mastery learning..

Based on this, the learning model can be used as an alternative that can make learning quality, one of which is the outdoor learning model. This model is also known by various other terms such as Outdoor Activities, Outdoor Study, field learning, or learning outside the classroom. Not a few experts have issued an opinion about Outdoor Learning. According to Husamah, Outdoor Learning is an activity outside of school that contains activities outside the classroom /school and in other outdoors[11], such as: playing in a school environment, parks, farming/fishing villages, camping, and other activities. Which is adventurous, as well as the development of relevant aspects of knowledge. According to her, outdoor education is defined as education that takes place outside the classroom which involves experiences that require student participation to take on adventure challenges that are the basis of outdoor activities such as hiking, mountain climbing, camping, and so on. So, this learning is interesting, fun, can be done in the surrounding environment that emphasizes the learning process based on actual facts, where learning materials are experienced directly through direct learning activities so that students can further build meaning or impressions, or memory [11].

There are benefit to use outdoor learning [11]. First, provide individuals with unique opportunities to develop creativity and personal initiative. Second, offers a meaningful setting for attitude formation. Third, helping to realize the potential of each individual so that his soul, body and spirit can develop optimally. Forth, Provide opportunities for children to experience firsthand the material presented. Fifth, enables students to enhance skills and interest in outdoor learning. Sixth, contributes to developing a better teacher-student relationship from some experiences in the outdoors. Seventh, provide opportunities to learn various things from handson activities. Lastly, utilizing sources from the environment and the surrounding community for learning.

Applying the model Outdoor Learning in Learning has several advantages. According to Sudjana and Rivai, there are many benefits obtained from activities learning environment in the learning process, including learning activities are more exciting and not boring for students, students don't just sit for a long time, making students' passion for learning increase [11]. Then, learning resources are wider, because the environment studied varies, there are social environments, natural environments, artificial environments, and others. Lastly, students can interpret life in their environment, giving rise to a personality that is familiar with their environment, and can increase their love for the environment. Based on the literature review 
above, this study aims to improve the cognitive learning outcomes of elementary school students in science lessons through the implementation of the model outdoor learning.

\section{Method}

This research is Classroom Action Research, which was conducted in six gradeof SD Negeri 1 KebaronganUPKKemranjen in 2018/2019. Research time from September to October 2018 which consisted of 2 cycles. Each cycle held two meetings with the same time allocation, namely 4 x 35 minutes in one cycle. The steps in this classroom action research consist of planning, implementing, observing, and reflecting, ${ }^{[12]}$ as in Figure 1.

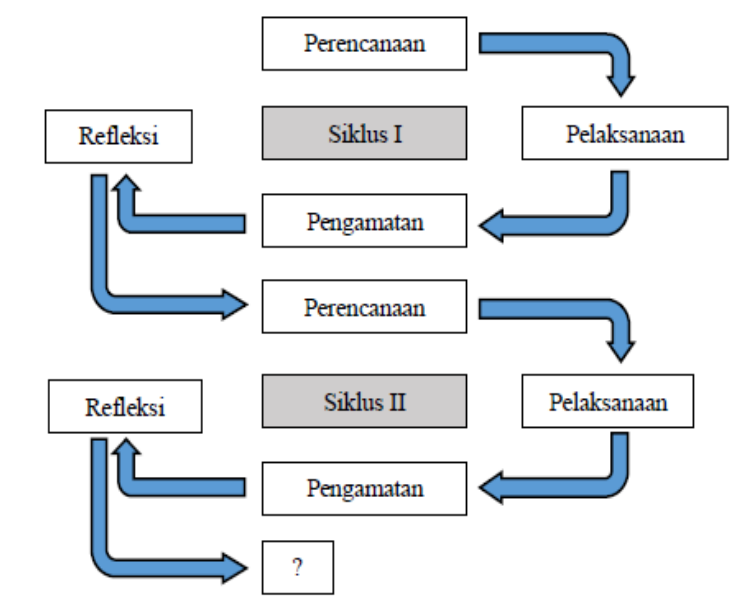

Figure 1. Classroom Action Research Cycle

The material used in this study is the subject matter of science on the copy of plants. In cycle 1, sub-material on generative reproduction of plants in cycle 2, sub-material on vegetative propagation of plants by learning the model Outdoor Learning.

The steps of the learning model Outdoor Learning, according to Hutama is: (1) The teacher carefully formulates the learning experience planned to obtain possible results or have alternatives; (2) Determining the form of activities to be used, this Outdoor Learning activity can be varied by the teacher. For example: in one material, it can be done in various forms, such as in other themes such as the environment; (3) The teacher tries to present experiences that are challenging and motivating; (4) Determine the timing of the activities; (5) Determine the route of travel outdoor learning, can be done in one class together. Outdoor learning can use the route around the school or in the neighborhood; (6) Students can work individually and can work in small groups: (7) Students actively participate in the formation of experiences; and (8) After all preparations are complete, the next stage of implementing activities is Outdoor Learning the teacher explains the rules of learning with outdoor learning.

The research subjects were $6^{\text {th }}$ grade students of SD Negeri 1 Kebarongan, there are twelve male and nine female. The type of data used is data during the pre-activity, during the activity, and after the learning action is carried out. The data collection tool was a research instrument used in the form of a post-test. To obtain valid data, especially quantitative data, a test kit consisting of a lattice for writing questions, question items, answer keys, and assessment criteria were made. The test kits include the post-test device cycle I and the post-test device cycle II. The form of post test questions is an essay that consists of 10 questions. The learning outcomes 
obtained by students at the end of the cycle are calculated then the presentation and the average class score are calculated. The formula for calculating the average (mean) adopted ${ }^{[13]}$ is as follows:

$$
\overline{\mathrm{X}}=\frac{\sum x}{N}
$$

$\begin{array}{cl}\overline{\mathrm{X}} & : \text { Average scores } \\ \Sigma & : \text { Total scores } \\ \mathrm{X} & : \text { Subject score } \\ \mathrm{N} & : \text { Number Subjects }\end{array}$

Meanwhile, to calculate the ratio of students who have completed the Minimum Completeness Criteria, the following formula is used:

$$
\%=\frac{\text { Ncompleted }}{N} \times 100 \%
$$

$\mathrm{N}_{\text {completed }}=$ Number of students who have completed

$\mathrm{N} \quad=$ Number of students

Actions in this study were said to be successful if at least $85 \%$ of 21 students experience an increase in cognitive learning outcomes above the minimum completeness criteria 70.

Table 1. Criteria Learning Success Rate Grade

\begin{tabular}{ccc}
\hline Percentage & Letter & Qualification \\
\hline $90 \%-100 \%$ & A & Very Good \\
$80 \%-89 \%$ & B & Good \\
$65 \%-79 \%$ & C & Enough \\
$55 \%-64 \%$ & D & Less \\
\hline$<55 \%$ & E & Failed / failed \\
\hline
\end{tabular}

\section{Results and Discussion}

\subsection{Results}

This study begins with observing of the initial conditions of learning in students by carrying out a pretest at subject matter plant propagation.

\section{Pre-action}

Pre-cycle implementation of pre-cycle activities in this study was carried out by collecting data done by researchers on plant vegetative propagation material. The learning process at State Elementary School 1 Kebarongan students listen to explanations then ask and answer questions after that work on the questions. In this learning, the teacher is more dominant. Learning that 
uses the approach teacher-centered makes students passive and difficult to understand the material. This is evidenced by the post-test average score of 63.33, and class completeness is $41 \%$. These results are quite low because the target of cognitive learning outcomes is 70.00 with a scale of 100 .

\section{Cycle I Actions}

Activities were conducted 2 times. The first meeting was held on October 2, 2018 for $2 \mathrm{x}$ 35 minutes by discussing material on plant breeding, the second meeting was held on October 9, 2018 for $2 \times 35$ minutes, by continuing the unfinished material at the first meeting for $1 \times 35$ minutes and cycle evaluation I for 1 x 35 minutes. The evaluation questions are given in written form as many as 10 essay questions.

\section{The First Meeting of Cycle I}

Planning in Classroom Action Research carried out several activities to prepare learning materials to be discussed, LESSON PLAN with the application of the Outdoor Learning Model, observation sheets of teacher activities and student activities, Computer/Laptop Learning media about Plant Breeding, evaluation questions (post-test) and scoring guidelines for evaluation questions. Furthermore, the implementation stage of the action is carried out, namely carry out the teaching and learning process in the classroom as outlined in the learning scenario. The activities carried out were implementing the Outdoor Learning Model in science learning for class VI SDN 1 Kebarongan to see the level of activity of teachers and students in teaching and learning activities. The initial activity is that the teacher enters the class and says greetings, before starting the lesson one of the students who that day is in charge of leading prayers accompanied by the teacher, followed by giving motivation and apperception. In the core activity, students listen to explanations about the material on vegetative propagation of natural plants displayed on the LCD.

Students are divided into seven groups consisting of 3 students because the class has formed a group, so the researcher and the teacher agree to use the existing group. Students listen to explanations about learning that will be carried out outside the classroom, precisely on the school grounds. Students and teachers leave the classroom neatly. Students observe what plants are around the schoolyard and how about their reproduction. Students fill out worksheets after wathcing various plants that are undergoing natural vegetative reproduction.

After wathcing and working on individual sheets, students and teachers enter the class again. Students convey the results of their observations and are responded to by teachers and students. The representatives of the group came forward to select an envelope in which there were pictures of various kinds of natural vegetative propagation of plants. Student representatives took envelopes containing multiple images of the vegetative propagation of plants according to the color desired by the group.

Students work on worksheets, in groups. Each group in turn, presented the results of the discussion in front of the class. Students paste the worksheets on the group boards that have been provided in front of the class. After all the groups have finished presenting the students and the teacher both conclude the material.In the final activity, an assessment and reflection are carried out by asking questions or responses from students from activities that have been carried out as input for the improvement of further action Students are given the task to bring examples of plants around their house to be observed at the next meeting. The teacher closes the lesson with a closing greeting. 


\section{Second Cycle I Meeting}

The initial activity at the teacher meeting entered the class it said greetings, as usual before starting the lesson one of the students who that day was in charge of leading prayers accompanied by the teacher and continued with giving motivation and apperception. One of the perceptions is by asking questions that provoke students' memories about the previous material. The core activity begins with the teacher's questions about the assignment given, namely the plants around the house that reproduce naturally.

One by one the students showed and mentioned the plants they brought. Shiva was then asked to borrow a plant and then wrote down the names and methods of reproduction from his ten friends. Students receive their work and the students respond and the teacher then concludes the activity. Students are allowed to ask things they do not understand and provoke their knowledge by providing simple questions. Students work on the evaluation questions (post-test) calmly. The teacher provides psychological encouragement to students to always study at home and not forget to worship. The teacher delivers the lesson plan at the next meeting. The teacher ends the lesson by saying thank God and greetings.

Results of Observation of Teacher Activities, observation of teacher activities in cycle I which includes opening lessons, mastery of teaching materials, strategies used, performance, media, materials, learning resources (Outdoor Learning), asking, reinforcement, and closing learning that has been observed during the learning process, the maximum number was 93 so that the percentage obtained was $75 \%$. Observation of teacher activities during the learning process is quite good with a score of 4 which means that it is very suitable for many eleven aspects, a value of 3 which means according to many 10 facotrs, a value of 2 which means that it does not match many nine aspects, and a value of 1 which means it is very inappropriate for many 1 factors. Even though there are some imperfect aspects, the teacher does not pay attention to systematics in learning, is not optimal in using the model Outdoor Learning, that a percentage of $75 \%$ is obtained which is included in the good category.

Observation results of the implementation of a cycle student activities, which include preparation, initial activities, core activities, and The final activity that has been observed by researchers during the learning process is the maximum number of 57 so that the presentation obtained is $67.85 \%$. Observation of student activities carried out during learning is quite good with a value of 4 which means that it is very suitable for many 5 facotrs, a value of 3 which means according to many 7 factors, a value of 2 which means that it does not match many 7 factors, and a value of 1 which means it is very inappropriate for many 2 factors. Even though some imperfect aspects, students are less active in answering questions from the teacher, expressing their opinions, and are busy. The results of the implementation of first cycle using the modelOutdoor Learning in science subjects vegetative reproduction material in plants obtained posttest results obtained an average of 72.38 with a percentage of $73 \%$ completeness which increased than before using the modelOutdoor Learning.

The reflection stage in the first cycle showed that the students' ability to understand the vegetative propagation material of plants showed an increase after using the modelOutdoor Learning in the first cycle, students were happier when they learned while playing outside the classroom. This can be seen when they walk around the schoolyard, which has not been used as a medium for carrying out teaching activities at SD Negeri 1 Kebarongan. Because the percentage of completeness obtained has not reached the results determined by the researcher, namely $85 \%$, In comparison, the share of completeness obtained by students in the first cycle is only $73 \%$ which is included in the sufficient criteria. Then the research was continued with cycle II. 


\section{Cycle II Action}

Based on the discussion result, the researcher and the teacher agreed that the research was carried out on 15, and 22 October 2018 before the implementation of teacher learning and the observer discussed the activities to be carried out. The researcher explains the learning activities that will be carried out by the lesson plan, the teacher responds enthusiastically. Planning cycle II is carried out as in cycle I, namely the researcher prepares a Learning Implementation Plan for two meetings based on the results of reflection and determination of alternative problem solving and program development from cycle I, observation sheets in the form of teacher activity observation sheets, student activity observation sheets, student learning outcomes both done individually in groups and products, the division of two large groups when outside the classroom and media planning outside the classroom. The difference between the planning cycle in the second cycle is that the learning activities that were originally observed around the school were extended to the environment around the school including the backyard of the school and added with pictures of plants where there was no school environment.

The initial activity at the first meeting of the second cycle the teacher entered the class. It said greetings, as usual before starting the lesson one of the students who that day was in charge of leading prayers accompanied by the teacher and continued with giving motivation and apperception by taking attendance, checking the neatness and readiness of students. One of the perceptions is by asking questions that provoke students' memories about the previous material. In the core activity, the students listened to the explanation of the natural and artificial vegetative propagation material displayed on the LCD, the students paid attention enthusiastically. The students were again divided into seven groups consisting of 3 students. Students listen to explanations about learning that will be carried out outside the classroom, precisely on the school grounds.

Students and teachers leave the classroom neatly. Students observe the plants in the schoolyard and take notes on their reproduction. Students fill out worksheets after watching plants in the schoolyard and pictures of plants given by the teacher. After the specified time is over, the students and the teacher return to class. Students work on worksheets in groups. Each group, in turn, presented their observations in front of the course. Other students and teachers responded enthusiastically. Each group was given an appreciation for the explanation. Students and teachers conclude the material.

In the final activity, an assessment and reflection are carried out by asking questions or responses from students from actions that have been carried out as input for the improvement of further action. The teacher provides psychological encouragement to students to always study at home and not forget to worship. The teacher delivers the lesson plan at the next meeting. Students are again given the task of observing the vegetative breeding of plants, both artificial and natural, around their home environment, and then recorded and delivered at the next meeting. The teacher ends the lesson by saying thank God and greetings.

Data from the implementation of observations of teacher activities in cycle II which includes opening lessons, mastery of teaching materials, strategies used, performance, media, materials, learning resources (Outdoor Learning), asking questions, reinforcement (providing reinforcement), and closing learning that has been observed during The learning process takes place, the maximum number of 119 is obtained with the percentage obtained is $95.96 \%$. The results of observations of the implementation of cycle II student activities which include preparation, initial actions, core activities, and final activities that have been observed by researchers during the learning process obtained a maximum number of 80 so that the percentage obtained is $95.23 \%$. 
The results obtained by students have increased compared to the results in cycle I, namely the average class value in first cycle reached 72.38 to 86.67 in cycle II. In addition, the students' enthusiasm in answering the teacher's questions, and expressing opinions in the first cycle the students were still not active, In contrast, in the second cycle the students were active in answering by raising their hands when they could answer. The following is the result of the recapitulation of student learning evaluation in cycle II:

In the implementation of the second cycle of learning, the results were very satisfying, and in accordance with the target set by the researcher, the completeness level reached $95.23 \%$. Both from student activities that are active, excited and conditioned in teacher actions that can provoke students to express opinions and learn,and activities using media during learning. These three aspects have increased significantly. Student cognitive learning outcomes is in Table 2.

Table 2. Cognitive Learning Outcomes

\begin{tabular}{lcccc}
\hline \multirow{2}{*}{ Value } & \multicolumn{3}{c}{ Action } & $\begin{array}{c}\text { Target } \\
\text { Scale (100) }\end{array}$ \\
\cline { 2 - 4 } & Pre- cycle & Cycle I & Cycle II & \\
\hline Average & 63.33 & 72.38 & 86.67 & 70 \\
\hline Increase & & 9.05 & 14.29 & $85 \%$ \\
\hline Completeness & $41 \%$ & $73 \%$ & $95 \%$ & \\
\hline Increase & & $32 \%$ & $22 \%$ & \\
\hline
\end{tabular}

\subsection{Discussion}

Table 2 shows an increase in the average cognitive learning outcomes from pre-cycle to first cycle of 9.05 and first cycle to second cycle of 14.29. Cognitive learning outcomes from cycle I to cycle II have also met the average target of completeness of $85 \%$.

Outdoor Learning is a learning model that is relevant to the contextual characteristics of plant breeding learning materials. Plants that are used as learning objects are those found in SD Negeri 1 Kebarongan. Learning that is carried out using objects directly makes students more enthusiastic in the learning process. Learning outside the classroom with the outdoor learning model makes learning more meaningful.

The results in Table 1 indicate an increase in cognitive learning outcomes. Increased cognitive learning outcomes because learning focuses more on students as learners, students not only listen, but also observe, identify, analyze, and communicate the concepts they find themselves. in line with some researcher stated that learning with the discovery process will be able to increase understanding of concepts and problem-solving abilities by students [14-16].

Daniel stated that students 'hands on activities during learning can increase students' interest and understanding which in turn result in high motivation and scientific achievement [17]. Learning Outdoor Learning students not only identify individual plants but also to discuss with friends and interact with the teacher. These results are supported by Akanmu and Fejenidagba and Hackathorn et al. stated that learning carried out together will produce more effective learning outcomes than individual learning or the lecture method [18-19]. The results of research conducted by Kao et al. concluded that through knowledge sharing (group activities) students become motivated to develop their knowledge [20].

The results of this study indicate that knowledge transfer activities can increase student activity in learning and improve learning achievement in the cognitive domain (understanding, conceptual organizing, and reflection). Outdoor learning facilitates students to interact with the surrounding environment to explore understanding independently or in groups. Harso also said 
that interactive occurs in various ways, including students with material, students with learning activities, students with teachers/facilitators and students with other students. Interactive learning also provides opportunities for students to do something according to their knowledge, thus supporting students to gain maximum knowledge [21].

Outdoor Learning also facilitates students to convey and explain the results of their investigations to other groups through presentation activities. The results of Magnesen's research explained that the memory level of students who learn by doing and communicating is very effective, reaching $90 \%$, on the contrary if students learn only by listening, reading or seeing, the memory level of students is less than 50 [22]. Through this learning, students learn in groups in making identification outside the classroom to making presentations. The teacher directs students to identify in groups and does not limit the identification process by students in terms of sources of information. Students not only learn to work together but also have to be responsible to their fellow students in achieving equitable knowledge. Barkley et al. The presentation stage provides an opportunity for students to exchange information because during the presentation there is interaction through question and answer so that students' knowledge can increase [23].

\section{Conclusion}

Outdoor learning can improve science learning outcomes on plant breeding material in grade VI students of State Elementary School 1 Kebarongan UPK Kemranjen. The results showed an increase in the class average score, namely the initial test average value of 63.33; first cycle 72,38; in the second cycle 86.67. For students completing learning on the initial test was $41 \%$, the first cycle test was $73 \%$, in the second cycle test the students studied completely reached $95 \%$. the results of observing teacher activities in cycle 1, the maximum number is 93 so that the percentage obtained is $75 \%$, in the second cycle it increases with a maximum number of 119 with the ratio obtained is $95.96 \%$. In the results of student activity observations obtained a maximum number of 57 so that the presentation obtained $67.85 \%$ in the first cycle and increased to $95.23 \%$ with the acquisition of a score of 80 .

This classroom action research can improve the quality of learning and student activity in school because this learning model has many advantages, such as increase cooperation and familiarity during the learning process and the school environment. In addition, this learning model creates openness to learning by exchanging ideas between students. For teachers, to improve understanding and learning achievement for students in applying different learning models in each lesson. To increase student activeness, creativity and effectiveness of learning, teachers are expected to provide assignments that involve students in the learning process.

Teachers are expected to facilitate the student learning process, both mentoring and preparing complete learning media and resources for students [24]. Teachers must be innovative in the learning process including selecting methods that are by the subject matter [25]. Researchers in carrying out classroom action research still have shortcomings, so researchers who want to study the same problems as researchers should have more references or supporting theories to complement existing deficiencies in research and use more innovative media so that students are more enthusiastic about learning process.

\section{Acknowledgments}

The author would like to thank those who have helped in the writing of this PTK report, namely, Mr. Yunan, S.Pd as the Principal of State Elementary School 1 Kebarongan who has granted research permission, colleagues in research, all teachers and The staff of State Elementary School 1 Kebarongan who have assisted implement classroom action research. 


\section{References}

[1] Türkkahraman M. The role of education in the societal development. Journal of educational and instructional studies in the world. 2012 Nov 1;2(4):38-41.

[2] Slamet A, Sudargotapilouw F, Rohman I. Critical Thinking Ability Analysis Beginning Teacher Candidates Of Biology in the Animal Physiology Material At Biology Education Program Fkip Sriwijaya University. Journal of Scientific and Research (IJSR). 2014;3(7):1038-42.

[3] Darmawan D. Inovasi Pendidikan. PT Remaja Rosdakarya. Bandung.2012

[4] Pandolfini V. Innovation and education systems: teachers experiencing Interactive Whiteboards. Journal of Scientific and Research Publications. 2013;3(10):1-8.

[5] Kazu IY, Kazu H, Ozdemir O. The effects of mastery learning model on the success of the students who attended "usage of basic information technologies" course. Journal of Educational Technology \& Society. 2005 Oct 1;8(4):233-43.

[6] Abdi A. The Effect of Inquiry-Based Learning Method on Students' Academic Achievement in Science Course. Universal journal of educational Research. 2014;2(1):37-41.

[7] Ahmed AK. Teacher-centered versus learner-centered teaching style. Journal of Global Business Management. 2013 Feb 1;9(1):22.

[8] Harjali H. Strategi guru dalam membangun lingkungan belajar yang kondusif: studi fenomenologi pada kelas-kelas sekolah menengah pertama di Ponorogo. Jurnal Pendidikan dan Pembelajaran (JPP). 2017 Dec 15;23(1):010-9.

[9] Ibrahim H, Sihkabuden S, Kustiawan U. Media pembelajaran: Bahan sajian program pendidikan akta mengajar. FIP. UM. 2001.

[10] Mulyasa. Kurikulum Tingkat Satuan Pendidikan. Bandung : PT Remaja Rosdakarya. 2010.

[11] Husamah. Pembelajaran Luar Kelas (Outdoor Learning). Jakarta :PrestasiPustaka Raya. 2013.

[12] Sukmadinata. Metode Penelitian Pendidikan. PT. RemajaRosdakarya. 2005.

[13] Arikunto S. Prosedur Penelitian Suatu Tindakan Praktik, Jakarta: Rieneke Cipta. 2010.

[14] Sulistyowati N, Widodo AT, Sumarni W. Efektivitas model pembelajaran guided discovery learning terhadap kemampuan pemecahan masalah kimia. Chemistry in education. 2012 Oct $8 ; 1(2)$.

[15] Bambang S, Anwar S. Pengembangan Model Pembelajaran Discovery Learning Ilmu Pendidikan untuk Meningkatkan Pemahaman Konsep Pendidikan Mahasiswa PGSD FIP UNY. Fakultas Ilmu Pendidikan Universitas Negeri Yogyakarta. Jurnal Penelitian Ilmu Pendidikan. 2009;2(1):54.

[16] Hussain M, Akhtar M. Impact of hands-on activities on students' achievement in science: An experimental evidence from Pakistan. Middle-East Journal of Scientific Research. 2013;16(5):626-32.

[17] Baker DP. The Effects of Implementing The Cooperative Learning Structure, Numbered Heads Together. Chemistry Classes at A Rural, Low Performing High School. 2013 Aug.

[18] Akanmu MA, Fajemidagba MO. Guided-discovery learning strategy and senior school students performance in mathematics in Ejigbo, Nigeria. Journal of Education and Practice. 2013;4(12):82-9.

[19] Hackathorn J, Solomon ED, Blankmeyer KL, Tennial RE, Garczynski AM. Learning by Doing: An Empirical Study of Active Teaching Techniques. Journal of Effective Teaching. 2011;11(2):40-54. 
[20] Kao GY, Lin SS, Sun CT. Beyond sharing: Engaging students in cooperative and competitive active learning. Journal of Educational Technology \& Society. 2008 Jul 1;11(3):82-96.

[21] Harsono D. Student-centered learning di perguruan tinggi. Jurnal Pendidikan Kedokteran dan Profesi Kesehatan Indonesia. 2008;3(1):4-8.

[22] Nicolls M. A second chance: AL in Iraq. Creative Associates International. dalam Paper of Education, Mobilization and Communication Division. 2004 Jul.

[23] Barkley EF, Cross KP, Major CH. Collaborative learning techniques: A handbook for college faculty. John Wiley \& Sons; 2014 May 6.

[24] Anggoro S, Widodo A, Suhandi A, Treagust DF. Using a Discrepant Event to Facilitate Preservice Elementary Teachers' Conceptual Change about Force and Motion. EURASIA J Math Sci Tech Ed. 2019;15(8):em1737.

[25] Hermita N, Ningsih HS, Alim JA, Alpusari M, Putra ZH, Wijaya TT. Developing Science Comics for Elementary School Students on Animal Diversity. Solid State Technol. 2020 Oct 16;63(1s). 